\title{
Treatment of unresectable stage IV metastatic melanoma with aviscumine after anti-neoplastic treatment failure: a phase II, multi-centre study
}

Uwe Trefzer ${ }^{1}$, Ralf Gutzmer ${ }^{2}$, Tabea Wilhelm³ ${ }^{3}$ Florian Schenck ${ }^{4}$, Katharina C Kähler ${ }^{5}$, Volkmar Jacobi ${ }^{6}$, Klaus Witthohn ${ }^{7}$, Hans Lentzen ${ }^{7^{*}}$ and Peter Mohr ${ }^{8}$

\begin{abstract}
Background: Aviscumine, a recombinant plant protein, is an immune modulator that induces ribotoxic stress at the $28 \mathrm{~S}$ ribosomal RNA subunit. In this way cytokine release and T-cell responses are enhanced. This phase II trial was conducted to test the efficacy and safety of aviscumine in patients with systemically pre-treated metastatic melanoma stage IV.
\end{abstract}

Methods: A total of 32 patients with progressive stage IV melanoma after failure of standard therapy were enrolled onto a single-arm, multi-centre, open-label, phase II trial. All patients had an ECOG performance status of 0 or 1. Patients received $350 \mathrm{ng}$ aviscumine twice weekly by subcutaneous injection until progression. The primary end points were progression-free survival (PFS) and overall survival (OS). Safety was assessed as adverse events (AEs). Tumor response was assessed every eight weeks and survival of patients was followed up to one year after the end of therapy. Thirty one patients (intent-to-treat population (ITT)) were assessed for efficacy; safety was assessed in the whole population.

Results: One patient achieved a partial response (PR) and 10 patients showed stable disease/no change (SD). The median progression-free survival (mPFS) was 63 days (95\% Cl 57-85) and median overall survival (mOS) was 335 days (95\% Cl 210-604). In total 210 treatment-emergent adverse events were recorded. Grade 1 or 2 AEs occurred in 72\% of patients and were mostly application-site effects such as pruritus Grade 3-4 treatment-emergent drug-related adverse events occurred in $9 \%$ of patients.

Conclusion: These results suggest that aviscumine may have a clinical impact in patients with previously treated metastatic melanoma and provide rationale for further clinical evaluation of this agent. In the light of effective new immune checkpoint blockers it might be a candidate for combinations with these agents.

Trial registration: ClinicalTrials.gov: NCT00658437

Keywords: Aviscumine, Cancer immunotherapy, CY-503, Metastatic melanoma stage IV, Phase II trial, Ribosome-inactivating protein

\section{Background}

Cutaneous malignant melanoma causes a small number of skin cancers but leads to nearly $80 \%$ of skin cancer deaths [1]. Annually, there are worldwide around 160,000 new cases of malignant melanoma with 41,000 deaths and it has the fastest rising incidence of all skin cancers among men and the second-fastest among women - which is

\footnotetext{
* Correspondence: h.lentzen@gmx.de

${ }^{7}$ MELEMA Pharma GmbH, Hamburg, Germany

Full list of author information is available at the end of the article
}

predicted to continue [2]. Prognosis for patients with stage IV metastatic melanoma is poor [3]. In a meta-analysis of 42 phase II trials, median survival was only 6.2 months, with a 1-year survival rate of $25.5 \%$ regardless of treatment regimen [4].

Dacarbazine (DTIC), the only chemotherapeutic agent approved in the US and in Europe for the treatment of metastatic melanoma, is associated with a response rate of $5-12 \%$ and a median overall survival of 5.6 to 9.1 months after the initiation of therapy [5-11]. 
Given the known immunogenicity of melanoma [12-14] many studies have evaluated the combination of chemotherapy with immunotherapy, particularly regimens containing interferon alfa and interleukin-2 (IL-2) [15]. These biochemotherapeutic approaches increase response rates but could not improve survival [16-18]. Also monoimmunotherapy with high dose IL-2 has never been shown to significantly prolong survival in phase III trials in patients with advanced stage IV melanoma [19,20]. In addition, IL-2 treatment-related toxicity is severe and often requires inpatient intensive care [21-23].

However, monotherapy with ipilimumab, a fully human monoclonal antibody (IgG1) that blocks CTLA-4 to promote antitumor immunity, has shown meaningful clinical activity including an improvement of overall survival in patients with metastatic melanoma in phase II and III studies [11,24-27].

Approximately 40 to $60 \%$ of cutaneous melanomas carry mutations in BRAF that lead to constitutive activation of downstream signalling through the MAPK pathway $[28,29]$. Therefore, treatment with selective BRAF and MEK inhibitors is restricted to patients with mutation-positive melanomas. Recently a phase III randomized clinical trial comparing vemurafenib, a potent inhibitor of mutated BRAF [30], with DTIC in patients with previously untreated, metastatic melanoma with a BRAF V600 mutation has shown improved rates of overall and progressionfree survival for vemurafenib [31]. Moreover, a phase III randomized clinical trial of previously untreated BRAF V600E mutated melanoma patients compared dabrafenib to dacarbazine and demonstrated improvements in RR (50 vs. $6 \%$ ) and PFS (5.1 vs. 2.7 months) [32]. Treatment of a similar patient population with the MEK inhibitor trametinib in those who had not previously received a BRAF inhibitor resulted in a median overall survival of 14.2 months and estimated 1-year survival of 59\% [33].

Aviscumine, a recombinant plant protein, is a class II ribosome-inactivating protein. The drug preferentially and specifically binds to cell-surface structures containing CD75s ( $\alpha 2,6$ sialolactosamine) [34-36]. CD75s structures are over-expressed in solid tumour cells $[37,38]$, in immune cells (e.g. granulocytes, monocytes/macrophages, B-cells) and in endothelial cells as well as in epithelial cells [39-43]. Binding enables internalisation of the drug and subsequent selective cleavage of the $\mathrm{N}$-glycosidic bond of the adenine- 4324 residue in the eukaryotic $28 \mathrm{~S}$ ribosomal RNA, thus inducing catalytic inactivation of the ribosomes and inhibition of protein synthesis ("ribotoxic stress") [44]. The "ribotoxic stress" induces T-cell responses, activation of natural killer cells, and antigen-presenting cells (APCs) (e.g. monocytes/macrophages, dendritic cells), and stimulation of cytokine release $[45,46]$. IL- $1 \beta$ and IFN- $\gamma$ seem to be the most relevant cytokines. The disease stabilisation in patients with advanced cancer observed in a phase I trial was associated with an increase of plasma levels of IL-1 $\beta$ and IFN- $\gamma[47]$.

Here we report results from a single-arm, multi-centre, open-label, phase II trial to investigate the efficacy and safety of subcutaneously administered aviscumine (CY-503) monotherapy in patients with unresectable stage IV metastatic melanoma after failure of one or more previous antineoplastic therapies.

\section{Results}

Between April 2008 and May 200932 pretreated patients with confirmed metastatic melanoma (stage IV) were included in the study. Baseline characteristics are shown in Table 1. Characteristics of patients, which are known to be prognostic in stage IV melanoma patients (age, sex, stage, and LDH), were well balanced. For efficacy analyses, 31 patients met the eligibility criteria and were evaluated as the ITT population.

The mean duration of treatment was 104.7 (SD 98.0) days. Patients received a mean of 6.2 (range 1-8) injections per cycle and 25.6 injections (range 1-127) overall. The most frequent reason for discontinuation of therapy was disease progression. 10 patients (32.3\%) had stable disease during the study, one patient showed partial response. The disease control rate (DCR) was $35.5 \%$ (11 of 31 patients) (Table 2). Median PFS was 63 days (95\% CI 57-85).

Kaplan-Meier analysis of OS was conducted. The observed mOS was 335 days (95\% CI 210-604) (Figure 1). Using a benchmark analysis according to Korn [4] the predicted mOS was 256 days (95\% CI 155-378). The predicted 1-year survival rate was 33.1\% (95\% CI 16.5-49.7) (historical 1-year OS) [4] in comparison to the observed 1-year survival rate of $45.0 \%$ (95\% CI 29.8-60.2). The hazard ratio for death was 0.75 (95\% CI 0.42-1.36), indicating a possible survival benefit in this study.

mOS data and 1-year-survival rates were analysed among patient subgroups (Table 3). There was no difference in $\mathrm{mOS}$ and 1-year survival rates between ECOG 0 and ECOG 1 subgroups or in the pretreatment groups. However, females showed a tendency to better 1-year survival (53.3\%) as compared to males (36.4\%). Patients showing disease control exhibited mOS of 14.3 months and a 1-year survival rate of $72.7 \%$ (Table 3). Interestingly, patients with an induced injection site reaction showed a longer survival (mOS: 445 days, 95\% CI: 335-604) compared to patients without induced injection site reactions (mOS: 155 days, 95\% CI: 67-210).

The safety population (32 patients) included all patients who had undergone randomization and who had received any amount of study drug. In total 210 AEs were recorded between the first dose and 30 days after the last dose of aviscumine. All 32 patients experienced at least one AE. The most frequent AEs were 


\begin{tabular}{|c|c|}
\hline Characteristic & Baseline values $(n=32)$ \\
\hline \multicolumn{2}{|l|}{ Sex } \\
\hline Male & $17(53.1 \%)$ \\
\hline Female & $15(46.9 \%)$ \\
\hline \multicolumn{2}{|l|}{ ECOG performance status } \\
\hline 0 & $17(53.1 \%)$ \\
\hline 1 & $15(46.9 \%)$ \\
\hline Mean age (range) - years & $65.4(20-85)$ \\
\hline \multicolumn{2}{|l|}{ M-stage } \\
\hline M1a & $4(12.5 \%)$ \\
\hline $\mathrm{M} 1 \mathrm{~b}$ & $4(12.5 \%)$ \\
\hline M1c & $24(75.0 \%)$ \\
\hline Visceral metastases & $28(87.5 \%)$ \\
\hline Non visceral metastases & $4(12.5 \%)$ \\
\hline \multicolumn{2}{|l|}{ LDH level } \\
\hline$</=$ Upper limit of the normal range & $18(56.3 \%)$ \\
\hline$>$ Upper limit of the normal range & $14(43.8 \%)$ \\
\hline \multicolumn{2}{|l|}{ Number of previous therapies } \\
\hline 1 & $17(53.1 \%)$ \\
\hline 2 & $7(21.9 \%)$ \\
\hline 3 & $4(12.5 \%)$ \\
\hline$\geq 4$ & $4(12.5 \%)$ \\
\hline \multicolumn{2}{|l|}{ Previous anticancer treatment } \\
\hline Chemotherapy ${ }^{*}$ & $29(90.6 \%)$ \\
\hline Immunotherapy ${ }^{* *}$ & $12(37.5 \%)$ \\
\hline Other anticancer therapy ${ }^{* * *}$ & $8(25.0 \%)$ \\
\hline
\end{tabular}

Data are number (\%) or mean. "Carboplatin, Cisplatin, DTIC, Fotemustine, Gemcitabine, Melphalan, Paclitaxel, Treosulfan, Vindesine, ${ }^{* *}$ IFN, Ipilimumab, Thymosin, ${ }^{* * *}$ CNTO, Genasense, Imatinib, Sorafenib, STA-4783-08.

application-site effects in $23(72 \%)$ patients. Fifty eight (27.6\%) AEs in 24 patients were deemed probably, possibly or certainly related to the study drug. Of these, most were NCI CTCAE grade 1 or grade 2; 8 (13.8\%) were grade 3-4 events (Table 4 ).

Table 2 Overall response and disease control rates (ITT population)

\begin{tabular}{ll}
\hline Response & $\mathbf{n = 3 1}$ \\
\hline Best overall $^{*}$ & 0 \\
Complete & $1(3.2 \%)$ \\
Partial & $10(32.3 \%)$ \\
Stable disease & $19(61.3 \%)$ \\
Progressive disease & $1(3.2 \%)$ \\
Not determinable & $11(35.5 \%)$ \\
Disease control rate ${ }^{\dagger}$ &
\end{tabular}

"Summary from site and central review; ${ }^{\dagger}$ Calculated as (complete response + partial response + stable disease)/number of patients.
Twelve SAEs occurred in five (16\%) of 32 patients. Two patients died from dyspnoea and tachyarrhythmia, respectively, but these events were not deemed to be related to the study drug. The other three patients had thrombocytopenia, cerebral ischaemia (both CTCAE grade 4 ), chest pain (CTCAE grade 3 ) and atrial fibrillation, dehydration, pneumonia, venous thrombosis, urinary tract infection and urosepsis (all CTCAE grade 3).

IgG and IgM anti-aviscumine antibody data were available for 29 patients. All except two patients developed IgG anti-aviscumine antibodies of different strength during the trial. One additional patient had an antiaviscumine IgG antibody titer at baseline. The titers were in the range $11-1,690 \mu \mathrm{g} / \mathrm{mL}$. Furthermore most of the patients with IgG antibody titer showed also an IgM titer. A correlation between anti-aviscumine antibody titers and PFS and OS, respectively, could not be detected (Cox regression analysis for PFS and OS, respectively: $\mathrm{p}>0.05)$.

\section{Discussion}

Aviscumine treatment at a dose of $350 \mathrm{ng}$ resulted in a median overall survival of 11 months and a 1-year survival rate of $45 \%$ in patients with unresectable metastatic malignant stage IV melanoma who had undergone previous treatment. The 1-year survival rate regarded as a key benchmark for comparing efficacy of novel therapeutics versus historical data is notably higher than the predicted value of $33.1 \%$ [4]. More than $70 \%$ of the patients had M1c disease indicating the presence of visceral metastasis, and more than $50 \%$ had elevated lactate dehydrogenase levels, both of which are associated with very poor survival $[4,48]$.

The hazard ratio for death is 0.75 (95\% CI 0.42-1.36) indicating a possible survival benefit in the aviscumine study compared with historical data of Korn et al. [4]. Also the median overall survival in our study (11 months) compares favorably with 8.4 months from a historical survival curve [4]. Nevertheless we have to state that the numbers enrolled are small.

In a phase II trial of sorafenib with temsirolimus (arm a) or tipifarnib (arm b) in untreated metastatic melanoma patients the median OS was 7 months in both treatment arms, while the number of patients achieving an objective response was seen in $4.7 \%$ and $2.6 \%$, respectively [49]. Ipilimumab (3 $\mathrm{mg} / \mathrm{kg}$ ), an anti-CTLA4 antibody, showed a 1-year survival rate of $39.3 \%$ and a median OS of 8.7 months in a phase II trial with $50 \%$ M1c patients [26].

In recent randomized, phase III trials involving patients with unresectable stage III or IV melanoma who had received previous treatment, 1-year survival rates were reported to be $22 \%$ to $38 \%$ with various treatment regimens $[50,51]$. The median overall survival in these 


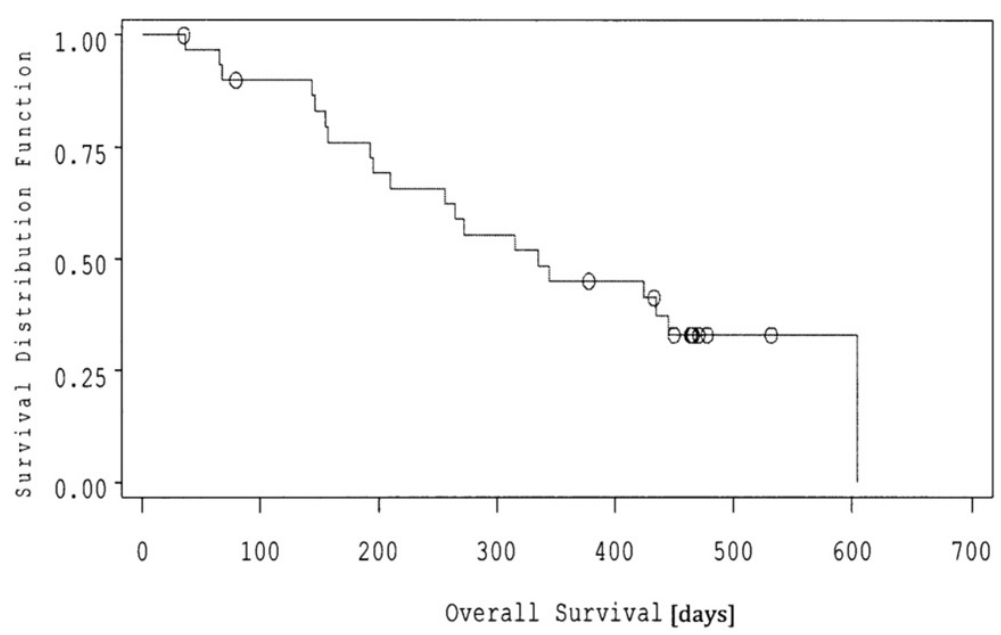

Figure 1 Kaplan-Meier estimates of overall survival by ITT population 0 censored numbers.

studies ranged from 5.9 to 9.7 months. Neither these nor other randomized, controlled trials had shown a significant improvement in overall survival.

However, ipilimumab was shown in two phase III, randomized, controlled trials to increase the survival in patients with unresectable metastatic melanoma (stage III and IV) as compared with a peptide vaccine from 6.4 to

Table 3 Survival by subgroup in ITT population

\begin{tabular}{|c|c|c|c|}
\hline \multirow[t]{2}{*}{ Subgroup } & \multirow{2}{*}{$\begin{array}{l}\text { Median OS } \\
(95 \% \mathrm{Cl}) \\
\text { months }\end{array}$} & \multicolumn{2}{|c|}{ 1-year survival rate } \\
\hline & & $\%$ & no./total no. \\
\hline Overall & $11.0(6.9-19.8)$ & 45.0 & $13 / 29$ \\
\hline \multicolumn{4}{|l|}{ Gender } \\
\hline Female & $13.9(6.9-19.8)$ & 53.3 & $8 / 15$ \\
\hline Male & $8.7(4.7-14.6)$ & 36.4 & $5 / 14$ \\
\hline \multicolumn{4}{|c|}{ Performance status } \\
\hline ECOG 0 & $10.8(6.9-19.8)$ & 43.8 & $7 / 16$ \\
\hline ECOG 1 & $11.0(5.1-19.8)$ & 46.8 & $6 / 13$ \\
\hline \multicolumn{4}{|l|}{ Metastasis stage } \\
\hline M1a & $14.6(10.3-14.6)$ & 66.7 & $2 / 3$ \\
\hline $\mathrm{M} 1 \mathrm{~b}$ & $19.8(1.2-19.8)$ & 75.0 & $3 / 4$ \\
\hline M1c & $8.8(6.3-14.3)$ & 36.4 & $8 / 22$ \\
\hline \multicolumn{4}{|l|}{ Age } \\
\hline$\leq 60$ years & $9.8(6.4-14.6)$ & 30.0 & $3 / 10$ \\
\hline$>60$ years & $13.9(6.3-19.8)$ & 53.1 & $10 / 19$ \\
\hline \multicolumn{4}{|l|}{ Pre-treatment } \\
\hline 1 & $11.3(6.9-13.9)$ & 46.9 & $7 / 15$ \\
\hline$\geq 2$ & $10.0(5.1-14.6)$ & 42.9 & $6 / 14$ \\
\hline \multicolumn{4}{|l|}{ Patients } \\
\hline Non-progressive & $14.2(11.3-19.8)$ & 72.7 & $8 / 11$ \\
\hline Progressive & $8.4(5.1-11.0)$ & 28.1 & $5 / 18$ \\
\hline
\end{tabular}

$\mathrm{OS}=$ overall survival, ITT = intention to treat, $\mathrm{Cl}$ confidence interval.
10.0 months [27] or with DTIC from 9.1 to 11.2 months [11]. Compared with the vaccine the 1-year survival rate was $45.6 \%$, but there was only a modest effect on rates of response and progression-free survival [27]. The use of ipilimumab combined with DTIC in patients with unresectable metastatic melanoma (stage III and IV) has also been associated with improved rates of survival over DTIC alone [11]. The 1-year survival rate in the firstline treated ipilimumab/DTIC arm was $47.3 \%$ and in the first-line placebo plus DTIC arm was 36.3\% [11].

In the context of published clinical experience with comparable patient populations, the 1-year overall survival rate of $62 \%$ and a median overall survival of 16.8 months associated with nivolumab, an immune checkpoint blocker of the anti-PD-1 antibody type, are particularly important [52].

Clinical activity of aviscumine was observed in all subgroups of patients, including patients with stage M1c disease. It was also seen both in ECOG 0 or in ECOG 1 patients. The median overall survival was 10.8 months vs. 11.0 months and the 1 -year survival rate was $44 \%$ vs. $47 \%$. This finding is interesting due to the known association between performance status and overall survival and the inclusion of the performance status as an important prognostic factor for stage IV melanoma patients $[4,53]$. The predicted 1-year overall survival rate for patients with visceral disease (M1b and M1c) was 23.8\% [4] in comparison to $42.3 \%$ in this study.

The median progression-free survival was 63 days and was not different to standard therapy. Also Hodi reported only a modest effect on rates of response and progression-free survival for the immunotherapeutic ipilimumab [27]. Regarding the immunotherapeutic approaches it is discussed that conventional definition of disease progression incompletely reflects the survival benefit $[54,55]$. 
Table 4 Drug-related adverse events $(n=58)$ for safety population $(n=32)$

\begin{tabular}{|c|c|c|c|c|c|}
\hline \multirow[t]{3}{*}{ Adverse effect } & \multicolumn{4}{|l|}{ Grade } & \multirow{3}{*}{$\begin{array}{l}\text { Total } \\
\text { n (\%) }\end{array}$} \\
\hline & 1 & n (\%) 2 & 3 & 4 & \\
\hline & n (\%) & n (\%) & n (\%) & n (\%) & \\
\hline Application site erythema & $2(6.3)$ & $1(3.1)$ & - & - & $3(9.4)$ \\
\hline Application site pain & $1(3.1)$ & $1(3.1)$ & - & - & $2(6.3)$ \\
\hline Application site pruritus & $1(3.1)$ & $1(3.1)$ & - & - & $2(6.3)$ \\
\hline Application site rash & $1(3.1)$ & - & - & - & $1(3.1)$ \\
\hline Application site reaction & $9(28.1)$ & $5(15.6)$ & - & - & $14(43.8)$ \\
\hline Application site swelling & $1(3.1)$ & & & & $1(3.1)$ \\
\hline Cerebral ischaemia & - & - & - & $1(3.1)$ & $1(3.1)$ \\
\hline Chills & $1(3.1)$ & - & - & - & $1(3.1)$ \\
\hline Decreased appetite & - & $1(3.1)$ & - & - & $1(3.1)$ \\
\hline Diarrhoea & $1(3.1)$ & - & - & - & $1(3.1)$ \\
\hline Dizziness & $1(3.1)$ & - & - & - & $1(3.1)$ \\
\hline Drug eruption & $1(3.1)$ & $1(3.1)$ & - & - & $2(6.3)$ \\
\hline Dry mouth & $1(3.1)$ & - & - & - & $1(3.1)$ \\
\hline Dyspnoea & - & - & - & $1(3.1)$ & $1(3.1)$ \\
\hline Erythema & $1(3.1)$ & - & - & - & $1(3.1)$ \\
\hline Fatigue & $3(9.4)$ & - & - & - & $3(9.4)$ \\
\hline Headache & $1(3.1)$ & - & - & - & $1(3.1)$ \\
\hline Hyperglycaemia & - & - & $1(3.1)$ & - & $1(3.1)$ \\
\hline Leukopenia & - & - & - & $1(3.1)$ & $1(3.1)$ \\
\hline Musculoskeletal discomfort & $1(3.1)$ & - & - & - & $1(3.1)$ \\
\hline Nasopharyngitis & $1(3.1)$ & - & - & - & $1(3.1)$ \\
\hline Nausea & - & $1(3.1)$ & - & - & $1(3.1)$ \\
\hline Neutropenia & - & - & - & $1(3.1)$ & $1(3.1)$ \\
\hline Night sweats & $1(3.1)$ & - & - & - & $1(3.1)$ \\
\hline Oedema peripheral & - & $1(3.1)$ & - & - & $1(3.1)$ \\
\hline Pruritus & $4(12.5)$ & - & $1(3.1)$ & - & $5(15.6)$ \\
\hline Pyrexia & $2(6.3)$ & - & - & - & $2(6.3)$ \\
\hline Thrombocytopenia & - & - & - & $1(3.1)$ & $1(3.1)$ \\
\hline Venous thrombosis & - & - & $1(3.1)$ & - & $1(3.1)$ \\
\hline Vision blurred & $1(3.1)$ & - & - & - & $1(3.1)$ \\
\hline Vulvovaginal mycotic infection & $1(3.1)$ & - & - & - & $1(3.1)$ \\
\hline Weight decreased & - & $1(3.1)$ & - & - & $1(3.1)$ \\
\hline Weight increased & $1(3.1)$ & - & - & - & $1(3.1)$ \\
\hline
\end{tabular}

Terms are from MedDRA (version 14.0) preferred terms, and grades are Common Toxicity Criteria of the National Cancer Institute (version 3.0). The drug-related adverse events occurred in 24 of 32 treated patients.

Overall, $35.5 \%$ of the patients treated with aviscumine met the criteria for a confirmed disease control (SD, PR), whereby most patients had SD. The high rate of $\mathrm{SD}$ may be viewed as an indicator of a meaningful therapeutic effect. Disease control due to SD is characteristic for immunotherapeutics and other biologics in cancer [54]. For example in a recent phase II combination trial of dendritic cell vaccination, interleukin-2 and metronomic cyclophosphamide the median OS was 9.4 months, while none of the patients achieved an objective response, but $57 \%$ of the patients achieved stable disease (SD) [56].

The confirmed DCR in our study is slightly higher than the DCR of $28.5 \%$ and $33.2 \%$ in the ipilimumab phase III trials [11,27]. Even in the EORTC phase I trial of aviscumine to treat solid malignant tumors, twice 
weekly subcutaneous injections up to $10 \mathrm{ng} / \mathrm{kg}$ body weight showed a disease control rate of $31 \%$, lasting from 11.3 to 35.7 weeks [47].

Patients receiving aviscumine reported only 8 drugrelated adverse events grade 3 or 4 . These were cerebral ischaemia, dyspnoea, hyperglycaemia, leukopenia, neutropenia, pruritus, thrombocytopenia and venous thrombosis. The majority of drug-related adverse events (application site reactions, grade 1 or 2) were immunerelated and consistent with the proposed mechanism of action of aviscumine. The patient with cerebral ischaemia started into the trial with known leukopenia and thrombocytopenia due to previous chemotherapy.

Subcutaneous injection of aviscumine induced antiaviscumine antibodies. The induction of these antibodies did not have any influence on the outcome parameters disease control rate and survival. Although the mechanism underlying the activity of aviscumine is not fully understood, it is known that the drug induces a strong immune response via pleiotropic mechanisms due to activation either of the innate or the adaptive immune system $[45,46]$.

In conclusion, the relatively high DCR and relatively long OS in patients with unresectable metastatic melanoma (stage IV), the good tolerability of $350 \mathrm{ng}$ aviscumine per injection after failure of dacarbazine or other previous therapies suggest that larger, randomized, controlled clinical trials also as treatment combinations considering the immune-related response criteria (irRC) [54] are now warranted.

\section{Conclusions}

Aviscumine treatment at a dose of $350 \mathrm{ng}$ (twice-weekly subcutaneously injected) resulted in clinical activity in patients with unresectable metastatic malignant stage IV melanoma who had undergone previous treatment. These results provide rationale for further clinical evaluation of this agent. In the light of effective new immune checkpoint blockers it might be a candidate for combinations with these agents.

\section{Methods}

\section{Patients}

Patients had to be at least 18 years old, with histologically confirmed stage IV melanoma with unresectable metastases and one or more measurable lesions. All patients had received at least one prior line of anti-neoplastic therapy. They had Eastern Cooperative Oncology Group (ECOG) performance status 0 or 1 , LDH $\leq 2.5$ ULN, serum creatinine levels $\leq 1.5 \mathrm{mg} / \mathrm{dL}$, absolute neutrophil count $\geq 1.5 \times$ $10^{9} / \mathrm{L}$, platelet count $\geq 100 \times 10^{9} / \mathrm{L}$, and life expectancy $\geq 3$ months. Patients had measurable disease according to Response Evaluation Criteria In Solid Tumors (RECIST) guidelines [57]. Exclusion criteria included pretreatment with mistletoe extracts, CNS metastasis, and ocular or mucosal melanoma.

\section{Study design}

The study was conducted at 4 centres in Germany between April 2008 and May 2010. Patients received twice-weekly subcutaneous injections of $350 \mathrm{ng}$ aviscumine in $1 \mathrm{~mL}$ solution in the thigh or abdomen. Injections were done on the same 2 days of each week ( 4 weeks $=1$ cycle), at least 3 days apart (e.g., Monday and Thursday, Tuesday and Friday).

Blood for analysis of anti-aviscumine antibodies was taken at baseline, at the end of every cycle and at the end of therapy. Anti-aviscumine antibodies (IgG and IgM) were measured with an ELISA using monoclonal anti-aviscumine antibody clone 36 (mouse, Cytavis BioPharma) and aviscumine bound to the titer plate. Detection was performed with anti-human IgG-POD and anti-human IgM-POD (both goat, Sigma-Aldrich) and colour reaction with TMB (Dako). Quantification of antibodies was performed in relation to standards: human IgG (Sigma-Aldrich), human IgM (Millipore).

Treatment was scheduled to continue without pause until disease progression (increase $\geq 20 \%$ in the sum of the longest diameters of the target lesions and/or new lesions) or a withdrawal criterion occurred. Withdrawal criteria were as follows: pregnancy or decision to become pregnant; toxic effects potentially related to the study drug that required discontinuation ( $\geq$ grade 3 hypersensitivity and haematological or non-haematological reactions confirmed after $48 \mathrm{~h}$ ); and other contraindication events (eg. illnesses or complications).

Supportive care and treatment of AEs were left to the investigator's discretion. Corticosteroids, immunostimulating substances and/or monoclonal antibodies were not allowed except for in life-threatening situations, when corticosteroids and colony-stimulating factors could be used. Antiemetics could be used if appropriate. Other anticancer agents were not allowed.

The study was carried out in compliance with current Good Clinical Practice, Ethics Committee recommendations, informed consent regulations, the Declaration of Helsinki [58] and with the laws and regulations of Germany. Approval was received from the local ethics committee and from the German health authority before recruitment started. All patients gave their written informed consent.

\section{Study outcomes}

The primary end points were overall survival (OS) and progression-free survival (PFS). OS was defined as time elapsed from random assignment to death from any cause. PFS was defined as time elapsed from random assignment to disease progression, or death, or start of new antitumor 
therapy. Up to 10 measurable lesions were assessed at baseline and every 8 weeks ( 2 cycles) according to RECIST guidelines. Independent evaluation of tumor images was performed by Institut $\mathrm{f}$. Diagnostische $\mathrm{u}$. Interventionelle Radiologie, Universitätsklinikum Frankfurt/M., Germany.

Secondary outcomes included disease control (complete remission (CR), partial remission (PR) or stable disease/no change (SD)), safety (defined by the occurrence and severity of AEs), and anti-aviscumine antibodies in blood serum.

Safety and tolerability assessment included observed AEs, clinical laboratory tests, physical examinations, and vital sign assessments. MedRA (version 14.0) approved descriptions and assigned grades according to the Common Toxicity Criteria of the National Cancer Institute (NCI CTCAE version 3.0) were used. AEs were classified as treatment-related or unrelated according to investigator judgement. If an $\mathrm{AE}$ occurred more than once, it was counted only once and given the maximum CTCAE grade.

\section{Statistical analysis}

\section{Determination of sample size}

Determination of sample size was based on PFS of 3 months. The proportion of patients with stage IV malignant melanoma showing PFS of at least 3 months under DTIC-based chemotherapy is $20 \%$. Only for the purpose of sample size planning, the value was increased to $40 \%$ and it was deemed that treatment would be unsuccessful if PFS at 3 months is $\leq 15 \%$. Therefore, it was estimated that 29 eligible patients would be required to reach $80 \%$ statistical power with $\alpha=0.05 .32$ patients should be recruited to allow for $10 \%$ dropout of non-evaluable patients. Simon's two-stage design was employed [59]. If 3 -month PFS is over the success threshold $(\leq 15 \%)$ in the first 13 recruited patients the trial will be continued.

\section{Efficacy analysis}

31 patients met the eligibility criteria (ITT population) and were included in the primary efficacy analysis. The survival of patients was followed for up to 12 months.

OS and PFS were estimated by constructing KaplanMeier curves. Patients lost to follow-up or not progressed at time of analysis were censored. Median overall survival (mOS) and median progression-free survival (mPFS) were deduced from the Kaplan-Meier curves. The 1-y survival rates were estimated from the individual survival data of the patients.

The immunological response in respect to the analysis of anti-aviscumine antibodies was examined using descriptive analysis.

\section{Safety analysis}

All patients who had received one or more dose of study treatment were included in the safety and tolerability analysis (safety population; $\mathrm{n}=32$ ). Treatment-emergent adverse events (AEs) were classified and graded using National Cancer Institute Terminology Criteria for Adverse Events version 3.0. AEs were also classified according to MedRA (version 14.0).

Variability estimates are expressed as standard deviation (SD) or 95\% confidence intervals (CI). Categorical variables are expressed as absolute values and percentages. Survival was estimated with the Kaplan-Meier product limit estimator, and median $(95 \% \mathrm{CI})$ survival times are reported. OS and PFS were calculated from randomization until the occurrence of the pertinent event or last observation. The information of death due to melanoma without documented progressive disease also qualified for PFS event. Cox's regression models were calculated for PFS and OS, with adjustment for following subgroups: ECOG performance status $(0,1)$, grade (no visceral, visceral), sex (male, female), age ( $\leq 60$ years, $>60$ years), number of previous treatments $(<2, \geq 2)$, and patients with disease control (non-progressive, progressive). Survival data were compared with predicted values calculated for each individual subject based on the prognostic variables included in the metaanalysis of Korn et al. [4] using the group of trials that excluded brain metastases. Survival analyses were made in the intention-to-treat (ITT) population and safety was assessed in all patients. Fisher's exact test was used to calculate two-sided significance values, with $\mathrm{p}<0.05$ deemed significant.

This study has not been previously presented in full or in part elsewhere.

\section{Competing interests}

Funding for the study was provided by CYTAVIS BioPharma GmbH, Hamburg, Germany.

\section{Authors' contributions}

$\mathrm{HL}, \mathrm{KW}, \mathrm{PM}, \mathrm{RG}$, UT participated in the study conception and design. PM was the principal investigator. FS, KK, RG, TW, UT were investigators. VJ carried out the independent evaluation of tumor images. HL, KW, UT drafted the manuscript. The approval of the manuscript was done by FS, HL, KK, KW, PM, RG, TW, UT, VJ. All authors approved and read the final manuscript.

\section{Acknowledgements}

The authors thank Beate Volkmer of Division of Molecular Cellbiology, Dermatology Center, Buxtehude, Germany for measuring the anti-aviscumine antibodies, Jennifer Schmitz and Michael Bulitta, CRMB, Rheinbach, Germany for data analysis. Manuscript writing assistance was provided by Kathryn Senior of Freelance Copy, London, UK.

\section{Author details}

${ }^{1}$ Dermatologikum Berlin, Berlin, Germany. ${ }^{2}$ Klinik für Dermatologie, Allergologie und Venerologie, Hauttumorzentrum Hannover (HTZH), Hannover, Germany. ${ }^{3}$ Charité- Universitätsmedizin Berlin, Hauttumorcentrum Charité (HTCC), Klinik für Dermatologie, Venerologie und Allergologie, Berlin, Germany. ${ }^{4}$ Hautärzte Zentrum Hannover, Hannover, Germany. ${ }^{5}$ Klinik für Dermatologie, Venerologie und Allergologie, Universitätsklinikum Schleswig-Holstein -Campus Kiel-, Kiel, Germany. ${ }^{6}$ Institut für Diagnostische Radiologie, Klinikum der Johann-Wolfgang-Goethe-Universität, Frankfurt/ Main, Germany. ${ }^{7}$ MELEMA Pharma GmbH, Hamburg, Germany. ${ }^{8}$ Elbe-Klinikum Buxtehude, Dermatologisches Zentrum, Buxtehude, Germany. 
Received: 27 March 2014 Accepted: 16 July 2014

Published: 19 August 2014

\section{References}

1. World Health Organization: Skin cancers. Accessed June 4, 2010, at http:// www.who.int/uv/fag/skincancer/en/index1.html.

2. Parkin DM, Bray F, Ferlay J, Pisani P: Global cancer statistics, 2002. CA Cancer J Clin 2005, 55:74-108.

3. Balch CM, Gershenwald JE, Soong SJ, Thompson JF, Atkins MB, Byrd DR, Buzaid AC, Cochran AJ, Coit DG, Ding S, Eggermont AM, Flaherty KT, Gimotty PA, Kirkwood JM, McMasters KM, Mihm MC Jr, Morton DL, Ross Ml, Sober AJ, Sondak VK: Final version of 2009 AJCC melanoma staging and classification. J Clin Oncol 2009, 27:6199-6206

4. Korn EL, Liu PY, Lee SJ, Chapman JW, Niedzwiecki D, Suman VJ, Moon J, Sondak VK, Atkins MB, Eisenhauer EA, Parulekar W, Markovic SN, Saxman S, Kirkwood JM: Meta-analysis of phase II cooperative group trials in metastatic stage IV melanoma to determine progression-free and overall survival benchmarks for future phase II trials. J Clin Oncol 2008, 26:527-534.

5. Chapman PB, Einhorn LH, Meyers ML, Saxman S, Destro AN, Panageas KS, Begg CB, Agarwala SS, Schuchter LM, Ernstoff MS, Houghton AN, Kirkwood JM: Phase III multicentre randomized trial of the Dartmouth regimen versus dacarbazine in patients with metastatic melanoma. J Clin Oncol 1999, 17:2745-2751.

6. Middleton MR, Grob JJ, Aaronson N, Fierlbeck G, Tilgen W, Seiter S, Gore M, Aamdal S, Cebon J, Coates A, Dreno B, Henz M, Schadendorf D, Kapp A, Weiss J, Fraass U, Statkevich P, Muller M, Thatcher N: Randomized phase III study of temozolomide versus dacarbazine in the treatment of patients with advanced metastatic malignant melanoma. J Clin Oncol 2000, 18:158-166.

7. Chiarion-Sileni V, Nortilli R, Aversa SML, Paccagnella A, Medici M, Corti L, Favaretto AG, Cetto GL, Monfardini S: Phase II randomized study of dacarbazine, carmustine, cisplatin and tamoxifen versus dacarbazine alone in advanced melanoma patients. Melanoma Res 2001, 11:189-196.

8. Avril MF, Aamdal S, Grob JJ, Hauschild A, Mohr P, Bonerandi JJ, Weichenthal M, Neuber K, Bieber T, Gilde K, Guillem Porta V, Fra J, Bonneterre J, Saiag P, Kamanabrou D, Pehamberger H, Sufliarsky J, Gonzalez Larriba JL, Scherrer A, Menu Y: Fotemustine compared with dacarbazine in patients with disseminated malignant melanoma: a phase III study. J Clin Oncol 2004, 22:1118-1125

9. Bedikian AY, Millward M, Pehamberger H, Conry R, Gore M, Trefzer U, Pavlick AC, DeConti R, Hersh EM, Hersey P, Kirkwood JM, Haluska FG: Bcl-2 Antisense (oblimersen sodium) plus dacarbazin in patients with advanced melanoma: the oblimersen melanoma study group. J Clin Oncol 2006, 24:4738-4745.

10. Schadendorf D, Ugurel S, Schuler-Thurner B, Nestle FO, Enk A, Bröcker E, Grabbe S, Rittgen W, Edler L, Sucker A, Zimpfer-Rechner C, Berger T, Kamarashev J, Burg G, Jonuleit H, Tüttenberg A, Becker JC, Keikavoussi P, Kämpgen E, Schuler G: Dacarbazine (DTIC) versus vaccination with autologues peptide-pulsed dendritic cells (DC) in first-line treatment of patients with metastatic melanoma: a randomized phase III trial of the DC study group of the DeCOG. Ann Ocol 2006, 17:563-570.

11. Robert C, Thomas L, Bondarenko I, O'Day S, Weber J, Garbe C, Lebbe C, Baurain J, Testori A, Grob J, Davidson N, Richards J, Maio M, Hauschild A, Miller WH Jr, Gascon P, Lotem M, Harmankaya K, Ibrahim R, Francis S, Chen T, Humphrey R, Hoos A, Wolchok JD: Ipilimumab plus dacarbazine for previously untreated metastatic melanoma. N Engl J Med 2011, 364:2517-2526.

12. Barnetson RS, Halliday GM: Regression in skin tumours: a common phenomenon. Australas J Dermatol 1997, 38(suppl 1):S63-S65.

13. Lee PP, Yee C, Savage PA, Fong L, Brockstedt D, Weber JS, Johnson D, Swetter S, Thompson J, Greenberg PD, Roederer M, Davis MM: Characterization of circulating T cells specific for tumor-associated antigens in melanoma patients. Nat Med 1999, 5:677-685.

14. Fang L, Lonsdorf AS, Hwang ST: Immunotherapy for advanced melanoma. J Invest Dermatol 2008, 128:2596-2605.

15. Sasse AD, Sasse EC, Clark LG, Ulloa L, Clark OA: Chemo-immunotherapy versus chemotherapy for metastatic malignant melanoma. Cochrane Database Syst Rev 2007, (1):CD005413.

16. Ridolfi R, Chiarion Sileni V, Guida M, Romanini A, Labianca R, Freschi A, Lo Re G, Nortilli R, Brugnara S, Vitali P, Nanni O: Cisplatin, dacarbazine with or without subcutaneous interleukin-2, and interferon alpha-2b in advanced melanoma outpatients: results from an Italian multicentre phase III randomized clinical trial. J Clin Oncol 2002, 20:1600-1607.

17. Bajetta E, Del Vecchio M, Nova P, Fusi A, Daponte A, Sertoli MR, Queirolo P, Taveggia P, Bernengo MG, Legha SS, Formisano B, Cascinelli N: Multicenter phase III randomized trial of polychemotherapy (CVD regimen) versus the same chemotherapy (CT) plus subcutaneous interleukin-2 and interferon-alpha2b in metastatic melanoma. Ann Oncol 2006, 17:571-577.

18. Punt CJ, Suciu S, Gore MA, Koller J, Kruit WH, Thomas J, Patel P, Lienard D, Eggermont AM, Keilholz U: Chemoimmunotherapy with dacarbazine, cisplatin, interferon-alpha2b and interleukin-2 versus two cycles of dacarbazine followed by chemoimmunotherapy in patients with metastatic melanoma: a randomised phase II study of the European Organization for Research and Treatment of Cancer Melanoma Group. Eur J Cancer 2006, 42:2991-2995.

19. Keilholz U, Stoter G, Punt CJ, Scheibenbogen C, Lejeune F, Eggermont AM: Recombinant interleukin-2-based treatments for advanced melanoma: the experience of the European Organization for Research and Treatment of Cancer Melanoma Cooperative Group. Cancer J Sci Am 1997, 3(Suppl 1):S22-S28.

20. Atkins MB: Cytokine-based therapy and biochemotherapy for advanced melanoma. Clin Cancer Res 2006, 12:2353s-2358s.

21. Parkinson DR, Abrams JS, Wiernik PH, Rayner AA, Margolin KA, Van Echo DA, Sznol M, Dutcher JP, Aronson FR, Doroshow JH: Interleukin-2 therapy in patients with metastatic malignant melanoma: a phase II study. J Clin Oncol 1990, 8:1650-1656.

22. Balmer CM: Clinical use of biologic response modifiers in cancer treatment: an overview. Part II: colony-stimulating factors and interleukin-2. DICP 1991, 25:490-498.

23. Bruton JK, Koeller JM: Recombinant interleukin-2. Pharmacotherapy 1994, 14:635-656

24. Weber J, Thompson JA, Hamid O, Minor D, Amin A, Ron I, Ridolfi R, Assi H, Maraveyas A, Berman D, Siegel J, O'Day SJ: A randomized, double-bind, placebo-controlled, phase II study comparing the tolerability and efficacy of ipilimumab administered with or without prophylactic budenoside in patients with unresectable stage III or IV melanoma. Clin Cancer Res 2009, 15:5591-5598.

25. O'Day SJ, Maio M, Chiarion-Sileni V, Gajewski TF, Pehamberger H, Bondarenko IN, Queirolo P, Lundgren L, Mikhailov S, Roman L, Verschraegen C, Humphrey R, Ibrahim R, de Pril V, Hoos A, Wolchok JD: Efficacy and safety of ipilimumab monotherapy in patients with pretreated advanced melanoma: a multicentre single-arm phase II study. Ann Oncol 2010, 21:1712-1717.

26. Wolchok JD, Neyns B, Linette G, Negrier S, Lutzky J, Thomas L, Waterfield W, Schadendorf D, Smylie M, Guthrie T Jr, Grob J, Chesney J, Chin K, Chen K, Hoos A, O'Day SJ, Lebbé C: Ipilimumab monotherapy in patients with pretreated advanced melanoma: a randomised, double-blind, multicentre, phase 2, dose-ranging study. Lancet Oncol 2010, 11:155-164.

27. Hodi FS, O'Day SJ, McDermott DF, Weber RW, Sosman JA, Haanen JB, Gonzalez R, Robert C, Schadendorf D, Hassel JC, Akerley W, van den Eertwegh AJM, Lutzky J, Lorigan P, Vaubel JM, Linette GP, Hogg D, Ottensmeier CH, Lebbé C, Peschel C, Quirt I, Clark JI, Wolchok JD, Weber JS, Tian J, Yellin MJ, Nichol GM, Hoos A, Urba WJ: Improved survival with ipilimumab in patients with metastatic melanoma. N Engl J Med 2010, 363:711-723.

28. Davies H, Bignell GR, Cox C, Stephens P, Edkins S, Clegg S, Teague J, Woffendin H, Garnett MJ, Bottomley W, Davis N, Dicks E, Ewing R, Floyd Y, Gray K, Hall S, Hawes R, Hughes J, Kosmidou V, Menzies A, Mould C, Parker A, Stevens C, Watt S, Hooper S, Wilson R, Jayatilake H, Gusterson BA, Cooper C, Shipley J, et al: Mutations of the BRAF gene in human cancer. Nature 2002, 417:949-954.

29. Curtin JA, Fridlyand J, Kageshita T, Patel HN, Busam KJ, Kutzner H, Cho KH, Aiba S, Bröcker EB, LeBoit PE, Pinkel D, Bastian BC: Distinct sets of genetic alterations in melanoma. N Engl J Med 2005, 353:2135-2147.

30. Bollag G, Hirth P, Tsai J, Zhang J, Ibrahim PN, Cho H, Spevak W, Zhang C, Zhang Y, Habets G, Burton EA, Wong B, Tsang G, West BL, Powell B, Shellooe R, Marimuthu A, Nguyen H, Zhang KY, Artis DR, Schlessinger J, Su F, Higgins B, lyer R, D'Andrea K, Koehler A, Stumm M, Lin PS, Lee RJ, Grippo $J$, et al: Clinical efficacy of a RAF inhibitor needs broad target blockade in BRAF-mutant melanoma. Nature 2010, 467:596-599.

31. Chapman PB, Hauschild A, Robert C, Haanen JB, Ascierto P, Larkin J, Dummer R, Garbe C, Testori A, Maio M, Hogg D, Lorigan P, Lebbe C, Jouary 
T, Schadendorf D, Ribas A, O'Day SJ, Sosman JA, Kirkwood JM, Eggermont AM, Dreno B, Nolop K, Li J, Nelson B, Hou J, Lee RJ, Flaherty KT, McArthur $\mathrm{GA}$ : Improved survival with vemurafenib in melanoma with BRAF V600E mutation. N Engl J Med 2011, 364:2507-2516.

32. Hauschild A, Grob JJ, Demidov LV, Jouary T, Gutzmer R, Millward M, Rutkowski P, Blank CU, Miller WH Jr, Kaempgen E, Martín-Algarra S, Karaszewska B, Mauch C, Chiarion-Sileni V, Martin AM, Swann S, Haney P, Mirakhur B, Guckert ME, Goodman V, Chapman PB: Dabrafenib in BRAF-mutated metastatic melanoma: a multicentre, open-label, Phase III randomised controlled trial. Lancet 2012, 380:358-365.

33. Kim KB, Kefford R, Pavlick AC, Infante JR, Ribas A, Sosman JA, Fecher LA, Millward M, McArthur GA, Hwu P, Gonzalez R, Ott PA, Long GV, Gardner OS, Ouellet D, Xu Y, DeMarini DJ, Le NT, Patel K, Lewis KD: Phase II study of the MEK1/MEK2 inhibitor Trametinib in patients with metastatic BRAF-mutant cutaneous melanoma previously treated with or without a BRAF inhibitor. J Clin Oncol 2013, 31:482-489.

34. Eck J, Langer M, Möckel B, Baur A, Rothe M, Zinke H, Lentzen H: Cloning the mistletoe lectin gene and characterization of the recombinant A-chain. Eur J Biochem 1999, 264:775-784.

35. Eck J, Langer M, Möckel B, Witthohn K, Zinke H, Lentzen H: Characterization of recombinant and plant derived mistletoe lectin and their B-chains. Eur J Biochem 1999, 265:788-797.

36. Müthing J, Burg M, Möckel B, Langer M, Metelmann-Strupat W, Werner A, Neumann U, Peter-Katalinic J, Eck J: Preferential binding of the anticancer drug rViscumin (recombinant mistletoe lectin) to terminally a2-6 sialylated neolactoseries gangliosides. Glycobiology 2002, 12:485-497.

37. Dall'Olio F, Chiricolo M, Ceccarelli C, Minni F, Marrano D, Santini D: $\beta$-Galactoside $a 2,6$ sialyltransferase in human colon cancer: contribution of multiple transcripts to regulation of enzyme activity and reactivity with sambucus nigra agglutinin. Int J Cancer 2000, 88:58-65.

38. Elpek G, Gelen T, Karpuzoglu G, Karpuzoglu T, Aksoy NH, Keles N: Clinicopathologic evaluation of cdw75 antigen expression in colorectal adenocarcinomas. Pathol Onc Res 2002, 8:175-179.

39. Wuensch SA, Huang RY, Ewing J, Liang X, Lau JT: Murine B cell differentiation is accompanied by programmed expression of multiple novel $\beta$-galactoside a2,6-sialyltransferase mRNA forms. Glycobiol 2000, 10:67-75.

40. Zimring JC, Levery SB, Kniep B, Kapp LM, Fuller M, Kapp JA: CD75s is a marker of murine $\mathrm{CD}^{+}$suppressor T cells. Int Immunol 2003, 15:1389-1399.

41. Cruse JM, Lewis RE, Wang H: Immunology Guidebook. Amsterdam; Boston: Elsevier Academic Press; 2004:47.

42. Jenner J, Kerst G, Handgretinger R, Müller I: Increased a2,6-sialylation of surface proteins on tolerogenic, immature dendritic cells and regulatory T cells. Exp Hematol 2006, 34:1212-1218.

43. Videira PA, Amado IF, Crespo HJ, Alqueró MC, Dall'Olio F, Cabral MG, Trindade H: Surface alpha 2-3- and alpha 2-6-sialylation of human monocytes and derived dendritic cells and its influence on endocytosis. Glycoconj J 2008, 25:259-268.

44. Langer M, Möckel B, Eck J, Zinke H, Lentzen H: Site-specific mutagenesis of mistletoe lectin: the role of RIP activity in apoptosis. Biochem Biophys Res Commun 1999, 264:944-948.

45. Hajto T, Hostanska K, Weber K, Zinke H, Fischer J, Mengs U, Lentzen H, Saller R: Effect of recombinant lectin, viscum album agglutinin on the secretion of interleukin-12 in cultured human peripheral blood mononuclear cells and on NK-cell-mediated cytotoxicity of rat splenocytes in vitro and in vivo. Nat Immunol 1998, 16:34-46.

46. Schaffrath B, Mengs U, Schwarz T, Hilgers RD, Beuth J, Möckel B, Lentzen H, Gerstmayer B: Anticancer activity of rviscumin (recombinant mistletoe lectin) in tumor colonization models with immunocompetent mice. Anticancer Res 2001, 21:3981-3988.

47. Bergmann L, Aamdal S, Marreaud S, Lacombe D, Herold M, Yamaguchi T, Wilhelm-Ogunbiyi K, Lentzen H, Zwierzina H: Phase I trial of rViscumin (INN: aviscumine) given subcutaneously in patients with advanced cancer: a study of the European Organisation for Research and Treatment of Cancer (EORTC protocol number 13001). Eur J Cancer 2008, 44:1657-1662.

48. Bedikian AY, Johnson MM, Warneke CL, Papadopoulos NE, Kim K, Hwu WJ, McIntyre S, Hwu P: Prognostic factors that determine the long-term survival of patients with unresectable metastatic melanoma. Cancer Invest 2008, 26:624-633.

49. Margolin KA, Moon J, Flaherty LE, Lao CD, Akerley WL 3rd, Othus M, Sosman JA, Kirkwood JM, Sondak VK: Randomized phase II trial of sorafenib with temsirolimus or tipifarnib in untreated metastatic melanoma (S0438). Clin Cancer Res 2012, 18:1129-1137.

50. Hauschild A, Agarwala SS, Trefzer U, Hogg D, Robert C, Hersey P, Eggermont AM, Grabbe S, Gonzalez R, Gille J, Peschel C, Schadendorf D, Garbe C, O'Day S, Daud A, White JM, Xia C, Patel K, Kirkwood JM, Keilholz U: Results of a phase III, randomized, placebo-controlled study of sorafenib in combination with carboplatin and paclitaxel as second-line treatment in patients with unresectable stage III or stage IV melanoma. J Clin Oncol 2009, 27:2823-2830.

51. Eisen $T$, Trefzer $U$, Hamilton A, Hersey $P$, Millward M, Knight RD, Jungnelius $J U$, Glaspy J: Results of a multicentre, randomized, double-blind phase $2 / 3$ study of lenalidomide in the treatment of pretreated relapsed or refractory metastatic malignant melanoma. Cancer 2010, 116:146-154.

52. Topalian SL, Sznol M, McDermott DF, Kluger HM, Carvajal RD, Sharfman WH, Brahmer JR, Lawrence DP, Atkins MB, Powderly JD, Leming PD, Lipson EJ, Puzanov I, Smith DC, Taube JM, Wigginton JM, Kollia GD, Gupta A, Pardoll DM, Sosman JA, Hodi FS: Survival, durable tumor remission, and long-term safety in patients with advanced melanoma receiving nivolumab. J Clin Oncol 2014, 32:1020-1030.

53. Gimotty PA, Guerry D, Flaherty K: Using benchmarks based on historical survival rates for screening new therapies for stage IV melanoma patients. J Clin Oncol 2008, 26:517-518.

54. Wolchok JD, Hoos A, O'Day S, Weber JS, Hamid O, Lebbé C, Maio M, Binder M, Bohnsack O, Nichol G, Humphrey R, Hodi FS: Guidelines for the evaluation of immune therapy activity in solid tumors: immune-related response criteria. Clin Cancer Res 2009, 15:7412-7420.

55. Hoos A, Eggermont AM, Janetzki S, Hodi FS, Ibrahim R, Anderson A, Humphrey R, Blumenstein B, Old L, Wolchok J: Improved endpoints for cancer immunotherapy trials. J Natl Cancer Inst 2010, 102:1388-1397.

56. Ellebaek E, Engell-Noerregaard L, Iversen TZ, Froesig TM, Munir S, Hadrup SR, Andersen MH, Svane IM: Metastatic melanoma patients treated with dendritic cell vaccination, Interleukin-2 and metronomic cyclophosphamide: results from a phase II trial. Cancer Immunol Immunother 2012, 61:1791-1804.

57. Therasse P, Arbuck SG, Eisenhauer EA, Wanders J, Kaplan RS, Rubinstein L, Verweij J, Van Glabbeke M, van Oosterom AT, Christian MC, Gwyther SG: New guidelines to evaluate the response to treatment in solid tumors. J Natl Cancer Inst 2000, 92:205-216.

58. WORLD MEDICAL ASSOCIATION: Ethical Principles for Medical Research Involving Human Subjects, Adopted by the 18th WMA General Assembly, Helsinki, Finland, June 1964, and amended by the 29th WMA General Assembly, Tokyo, Japan, October 1975; 35th WMA General Assembly, Venice, Italy, October 1983; 41st WMA General Assembly, Hong Kong, September 1989; 48th WMA General Assembly, Somerset West, Republic of South Africa, October 1996; and the 52nd WMA General Assembly, Edinburgh, Scotland, October 2000; Note of Clarification on Paragraph 29 added by the WMA General Assembly, Washington 2002; Note of Clarification on Paragraph 30 added by the WMA General Assembly, Tokyo 2004 (Declaration of Helsinki).

59. Simon R: Optimal two-stage designs for phase II clinical trials. Control Clin Trials 1989, 10:1-10.

doi:10.1186/s40425-014-0027-z

Cite this article as: Trefzer et al.: Treatment of unresectable stage IV metastatic melanoma with aviscumine after anti-neoplastic treatment failure: a phase II, multi-centre study. Journal for ImmunoTherapy of Cancer 2014 2:27.

\section{Submit your next manuscript to BioMed Central and take full advantage of:}

- Convenient online submission

- Thorough peer review

- No space constraints or color figure charges

- Immediate publication on acceptance

- Inclusion in PubMed, CAS, Scopus and Google Scholar

- Research which is freely available for redistribution 